\title{
A visão pós-moderna de prazer e os desafios à vida cristã: uma reflexão ético-teológica sobre a formação da consciência do sujeito cristão
}

\author{
The post-modern vision of pleasure and the challenge to \\ Christian life: an ethical-theological reflection on the \\ formation of the conscience of the Christian subject
}

André Luiz Boccato de Almeida

Lúcia Eliza Ferreira da Silva

\section{Resumo}

O presente artigo pretende analisar o tema do prazer no contexto da pósmodernidade com o seu impacto na formação do sujeito cristão. Essa é uma questão que interpela a consciência diante da complexidade de integração da pessoa em todos os aspectos. O tema do prazer, na tradição cristã, foi sempre relegado a uma visão antropológica dualista e repressora, nem sempre sendo compreendido na totalidade da vida da pessoa. Com a pós-modernidade, o prazer desloca-se de uma visão antropológica integral para uma perspectiva fragmentada e reducionista. Diante deste cenário, em um primeiro momento, serão abordadas as marcas e heranças da culpa e do prazer na tradição cristã. Posteriormente, focar-se-á acerca do dilema do prazer na cultura propriamente pós-moderna. Enfim, numa perspectiva ético-teológica, propor-se-á uma reflexão em torno do aspecto formativo, condição essencial para a vida do sujeito cristão.

Palavras-Chave: Culpa. Prazer. Pós-modernidade. Consciência. Formação.

\section{Abstract}

This article intends to analyze the theme of pleasure in the context of post-modernity with its impact on the formation of the Christian subject. This 
is a question that challenges the conscience in face of the complexity of the person's integration in all aspects. The theme of pleasure, in the Christian tradition, has always been relegated to a dualistic and repressive anthropological vision, not always being understood in the totality of a person's life. With postmodernity, pleasure shifts from an integral anthropological vision to a fragmented and reductionist perspective. Given this scenario, at first, the marks and heritages of guilt and pleasure in the Christian tradition will be addressed. Subsequently, it will focus on the pleasure dilemma in post-modern culture properly. Finally, from an ethical-theological perspective, a reflection on the formative aspect will be proposed, an essential condition for the life of the Christian subject.

Keywords: Guilt. Pleasure. Postmodernity. Conscience. Training.

\section{Introdução}

O tema do prazer relacionado à experiência cristã esteve sempre marcado por conflitualidades e desentendimentos diante da matriz antropológica que apoiou tradicionalmente a fé de inspiração cristã nos seus primórdios. Isto é justificável pelo fato de que uma coisa é o evangelho de Jesus Cristo, outra coisa é o sistema religioso complexo que se apresenta hoje em dia como cristianismo e que é o resultado de dois mil anos de miscigenação com muitas religiões humanas, principalmente aquelas que floresceram na bacia do Mediterrâneo. É o cristianismo como religião.

Este artigo pretende confrontar a dimensão antropológica do prazer humano à visão pós-moderna de corporeidade que aos poucos vem se impondo na mentalidade cultural ocidental. O corpo tanto pode ser instrumentalizado pelas culturas como também pelas religiões. Historicamente o cristianismo assumiu um modelo antropológico dualista e rigorista que comprometeu uma visão positiva sobre o prazer e as forças interiores que em si não são más. As culturas, que nascem e se desdobram à sombra das religiões, instrumentalizam os corpos humanos e o prazer na medida em que se impõe como uma complexidade simbólica de poder em um ethos que pretende se impor com uma narratividade única.

Nesta reflexão, visa-se refletir o tema do prazer no contexto pósmoderno, indicando os desafios postos à perspectiva cristã no viver de forma integral. Esta realidade é um desafio à consciência e sua formação justamente 
porque refere-se à própria capacidade pessoal de cada sujeito responder e decidir como protagonista no seu agir. Para atingir tal objetivo, será trilhado o seguinte caminho. Num primeiro momento, abordará as marcas e heranças da culpa e do prazer na tradição cristã com suas influências históricas na antropologia. Posteriormente, será apresentado o tema do prazer no contexto pós-moderno com suas características e desafios. Enfim, o problema geral indicado será problematizado pela questão da consciência em seu aspecto propriamente formativo e ético.

\section{Marcas e heranças da culpa e do prazer na tradição cristã}

A religião, principalmente na cultura ocidental cristã, foi sempre uma instância de determinação sobre o que é o corpo e como este deve se "comportar" no corpus maior que é a sociedade, instaurando um equilíbrio entre o sujeito particular e o todo maior que ele ocupa. Esta foi uma lenta construção em busca de um determinado equilíbrio da carne, por meio de um sutil mecanismo ou dispositivo de "repressão" das manifestações corporais, dentre elas, o prazer.

A ênfase na dimensão espiritual revela a tendência - de matriz platônicoestoica - que prevaleceu, principalmente com a construção de um discurso religioso que nem sempre prioriza as dimensões mais profundas do ser humano e do seu corpo, mas enfatiza a existência humana sob a prática de um pastoreio administrador da culpa.

O fenômeno modernista encarrega-se de provocar este contexto de sujeitos apequenados diante do sentimento de culpa, desarmonizando hábitos antigos aos novos, repercutindo na existência do sujeito em seu exercício da razão - a liberdade empírica-argumentativa; a autoridade da subjetividade frente a lei objetiva - a verdade provinda não do objeto (lei); e, o movimento da história - sendo um processo em contínua metamorfose. Desta forma, estes três elementos constituem o enfrentamento às convicções religiosas, como às fórmulas da fé e observância as mesmas. ${ }^{1}$

Com a ausência dessa tríade de fatores, se constituiu e ainda permanece fortemente a performance de certos movimentos religiosos que fortalecem a imagem puritana do Cristo da fé distante do Jesus de Nazaré histórico - núcleo da profissão de fé - cuja prática indicou uma nova modalidade de homem, pautada no horizonte da felicidade, frente à rigidez solene e imponente dos agentes religiosos.

${ }^{1}$ SALZMAN, T. A.; LAWLER, M. G., A pessoa sexual, p. 23-24. 
Segundo Castilho, estes grupos proclamam um regime de censura que "proíbe e exige, a fazer com que as pessoas se sintam culpadas por coisas das quais afirma-se que nada têm em si de culpabilidade" ${ }^{2}$ e, se estruturam com base nos aspectos e na busca extravagante da pureza como principal vereda para a salvação superando a prática da justiça.

Ainda sobre a descrição da pessoa de Jesus Cristo e seus desdobramentos na moralidade dos fiéis, Ranke-Heinemann atribui essa determinação do exercício redentor do Cristo - livre de qualquer prazer e a buscar desmedidamente a continência e a castidade - às concepções pessimistas acerca do corpo e do prazer, transcorrendo a pessoa inspiradora do Cristo avesso ao gozo durante o processo redentor. Assim descreve:

Embora Jesus não fosse asceta e tampouco panegirista da castidade, este ideal gradualmente se disseminou pelo mundo cristão. O tribunal nega a Jesus todo e qualquer tipo de prazer, embora provavelmente só tenha um desses em mente. Ao mesmo tempo, vincula o prazer sexual de forma tão próxima ao conceito de "pecado" que uma outra questão legal deveria ser esclarecida: o prazer sexual não é uma coisa boa e um antigo ponto de vista católico: não pode haver prazer sexual sem pecado. Jesus era aquela espécie de Redentor sexualmente "apático" que odiava a luxúria. O cristianismo e o pessimismo sexual foram sempre um casal pudico. ${ }^{3}$

Para o desenvolvimento desta moralidade sexual cristã pessimista, duas influências foram cruciais. Primeiro, o judaísmo, como contexto das primeiras comunidades cristãs, em simultâneo com o fundamento ápice da criação do homem e da mulher por um Deus reinante que os abençoa, tornando-os fecundos e bons (Gn 1,22). Sendo esse ser divino, constituído como O verdadeiro, que inspira à vida reta, ${ }^{4}$ por intermédio de sua própria palavra como orientador moral e fonte de prazer na observância dos mandamentos (S1 119,4748.112.141) e na disciplina ( $\operatorname{Pr} 29,17-18)$.

Em contrapartida, o exercício do desejo e do prazer, fora desses princípios, é configurado por penalidade grave, como no: exercício da masturbação / perda de sêmen (Gn 38,9-10; Lv 15,16-17); as expressões de desejo (Mt 5,28; 1Pd 2,11; Rm 13,14) e nos atos homossexuais (Gn 19,1-11; Lv 18,22; 20,13; Rm 1,26-27; 1Cor 6,9; 1Tm 1,10).

\footnotetext{
${ }^{2}$ CASTILHO, J. M., A ética de Cristo, p. 192.

${ }^{3}$ RANKE-HEINEMANN, U., Eunucos pelo Reino de Deus, p. 59.

${ }^{4}$ VS 3.
} 
Segundo aspecto foi o gnosticismo, pela promoção idealista do celibato, conforme: Pitágoras (século VI a.C) - na moderação do sexo como preservação da saúde; o potencial perigo, incontrolável e prejudicial à vitalidade para Xenofonte, Platão, Aristóteles e Hipócrates (século IV a. C); e, na escola filosófica estoica, de 300 a.C a 250 d.C., com o comportamento austero e o desejo incabível e passível de excesso. ${ }^{5}$ Assim, engana-se quem aponta como ação inovadora do cristianismo o exercício do autocontrole frente aos prazeres, pois encontra-se na história pré-cristã tal pessimismo e punição frente aos deleites. Contudo, no caminhar da história, tais técnicas punitivas e perspectivas avessas ao prazer são aperfeiçoadas, a fim de possibilitar uma leitura antropológica no ambiente cristão cada vez mais idealista e pessimista acerca do sujeito, como em Agostinho e no movimento jansenista.

Tendo como fontes inspiradoras essas compreensões, a doutrina cristã passará a estabelecer normativas sobre o prazer, a partir de seus próprios contextos culturais, na tentativa de defesa dos seus valores frente aos "erros" que ameaçariam o ideal cristão. Dessa maneira, a organização institucional se dará em companhia de um exercício hermenêutico que conduzirá o ensinamento não pautado na situação sócio-histórica dos indivíduos, mas na meta de constituir a plena unidade entre alma e corpo para justificar seus próprios atos morais. ${ }^{6}$

No que diz respeito a esses determinismos da tradição cristã, Michel Foucault indica essas práticas doutrinas como técnica de uma evolução disciplinar por parte da pastoralidade do cristianismo de ritualização de verdades, onde o sujeito se insere no momento de verbalização sobre si, a partir da articulação com a obediência praticada sob um regime de atos e prazeres. ${ }^{7}$

Segundo Foucault, essa instituição disciplinar passa a ser mais eficaz no mecanismo observador do sujeito quando define meandros de verificação de verdade pela direção de consciência e formas de confissão penitencial, o que passa a configurar precisamente uma trilha de remissão, purificação e manifestação das faltas e dos segredos. Pois, apresentando-se a um outro - atos, pensamentos e culpas -, pedisse um conselho direcionador, colocando no centro da fala o "dispositivo do problema da carne - compreendida como modo de experiência, conhecimento e transformação de si por si", ${ }^{8}$ a propósito do bom êxito do domínio de si em face das ditas fraquezas.

\footnotetext{
${ }^{5}$ SALZMAN, T. A.; LAWLER, M. G., A pessoa sexual, p. 33.

${ }^{6}$ VS 48.

${ }^{7}$ FOUCAULT, M., História da sexualidade IV, p. 13.

${ }^{8}$ FOUCAULT, M., História da sexualidade IV, p. 64.
} 
Esse poder disciplinador gera corpos dóceis e domesticados, incapazes de conviver com os impulsos naturais de desejo, a configurar uma existência sob o exercício repressor, a fim de preservar seu segredo límpido. Uma forma desse projeto atuar é pelo confessionário católico, que: discrimina expressões sexuais pessoais, interpreta e interpela à confissão - a versar a partir do sentimento de culpa gerado pela censura- ao se confrontar com ideais irreais. ${ }^{9}$

Dado que, partindo do princípio do "homem de desejo", e este prazer sendo "não constante e a-histórico, mas sim uma categoria isolada a partir da experiência cristã da carne, como marca originária da natureza decaída e herdada pela experiência moderna" ${ }^{10}$ a sexualidade se decifra ao confessar-se pelo sujeito que deseja algo, estabelecendo "de si para consigo uma certa relação que lhes permite descobrir, no desejo, a verdade de seu ser, seja ele natural ou decaído". ${ }^{11}$

A partir desse exercício de poder, a possibilidade do surgimento de indivíduos com sexualidades problemáticas ou compulsivas é emergente pelo fato que, segundo Giddens, ${ }^{12}$ através da representação obsessiva e ao mesmo tempo frágil, do controle para o afastamento emocional das circunstâncias, eleva a potencial tendência à violência por autores na face pessoal à rigorosa ortodoxia, porque estes que exaltam os ditos comportamentos normais promovem ao mesmo tempo o sofrimento e a morte. Pois, sem a execução de um juízo crítico e íntegro, há o empobrecimento de afeto.

Nessa perspectiva de prazer domesticado, vê-se a idealização de sujeito e seu relacionamento com suas próprias vibrações a partir de uma semântica religiosa disposta a reproduzi-la perpetuamente, velando corpos e subjetividades na contemporaneidade. Acerca disso, a prática tradicional católica, tem adotado mais fortemente as explicações conservadoras do magistério do pontificado de João Paulo II acerca do corpo, eliminando aspectos mais profundos do eu em virtude de uma apologética dos costumes e da pureza, revelando um mal-estar entre "uma doutrina constante e uma realidade em contínua mudança". ${ }^{13}$

Visto que, para essa casta religiosa, haveria uma antropologia adequada firmada exclusivamente nos textos bíblicos e em seus "fiéis" intérpretes, os quais manifestariam o perfeito contexto teológico da imagem de Deus

\footnotetext{
${ }^{9}$ FOUCAULT, M., História da sexualidade I, p. 23.

${ }^{10}$ CIRINO, O., O desejo, os corpos e os prazeres em Michel Foucault, p. 311.

${ }^{11}$ FOUCAULT, M., História da sexualidade IV, p. 10.

${ }^{12}$ GIDDENS, A., A transformação da intimidade, p. 126.

${ }^{13}$ ZACHARIAS, R., Repensar a moral sexual, p. 287.
} 
manifestada na revelação do homem através do seu corpo, determinam o indivíduo como pessoa através de sua corporeidade ${ }^{14}$ debilitando dimensões mais internas e pessoais. Mesmo que na atualidade não se tenha testemunhado avanços significativos nesse campo, existe no magistério de Francisco a inspiração de confrontar os "prazeres vazios de domínio sobre os outros" 15 - o que cabe muito bem no exercício da pastoralidade sobre a culpa e o desejo, como na abordagem mais lúcida a respeito do desejo, promovendo um "erotismo mais saudável", a fim de, "humanizar os impulsos", ${ }^{16}$ vendo-o como dom, beleza e dignidade.

Sendo assim, pela multifacetada cultura contemporânea, marcada por discursos e percepções sobre o sujeito cada vez mais díspares, é real que a linguagem religiosa posta é insuficiente quando se fixa em seus determinismos. Visto que a pluralidade no corpo social oferece ao sujeito o protagonismo de efetivar suas decisões e vontades, é preponderante a promoção do amadurecido exercício da subjetividade do sujeito, diante de estruturas que fragmentam seus desejos e prazeres. Portanto, a sugestão é encontrar caminhos para a vivência autêntica do prazer não objetivando as pulsões reais do sujeito - no enquadrar a felicidade em proibições ditas como divinas - como também, não patentear formas egoístas de liberdade do homem moderno.

\section{O dilema do prazer na cultura pós-moderna}

Tendo em vista que na tradição cristã foi possível observar os meandros pelos quais a concepção de prazer precisou atravessar, na pós-modernidade essa concepção surge de forma plural, fragmentada e reducionista. Ao passo em que a humanidade atravessa uma grande crise, ela assiste ao advento de inúmeros dilemas que por sua vez, caracterizam a era pós-moderna: a fragmentação da vida humana, a valorização de uma moral hedonista, a ascensão do niilismo e com ele a ausência de valores e de sentido para a vida, o apego ao narcisismo exacerbado, uma ampla adesão ao consumismo e, dentre as diversas peculiaridades, ainda é possível ver como um forte ideal o individualismo sem precedentes.

Diante de um cenário tão plural, é possível afirmar que a pósmodernidade resulta numa série de estilos que "convivem sem briga no mesmo saco". ${ }^{17}$ Já não se busca mais afirmar o conceito de identidade como antes

\footnotetext{
${ }^{14}$ JOÃO PAULO II, PP., Homem e mulher o criou, p. 83.

15 GE 121.

${ }^{16}$ AL 151.

${ }^{17}$ SANTOS, J. F., O que é pós-moderno?, p. 64.
} 
porque, nesta profunda transformação, o sujeito só tende a caminhar para uma contínua fragmentação. ${ }^{18} \mathrm{E}$, neste emaranhado de comportamentos, vai sendo idealizado um novo estilo de vida que é mais livre, narcísico e hedonista.

É possível observar que na cultura pós-moderna surge um imperativo: o direito ao prazer. Este direito é ancorado na "liberdade dos costumes", nascido com a Revolução Sexual de 1968, e tem como pilar sustentador, a transgressão da moral tradicional e a suspensão dos tabus que regiam a sociedade. ${ }^{19}$ No tocante às repercussões da visão de prazer na sexualidade pós-moderna, Lipovetsky afirma que algo bastante notório está no fato de que ela consagrou a possibilidade de viver sem sentido, ou seja, de não crer na existência de um único categórico sentido, mas de apostar na construção permanente de sentidos múltiplos, provisórios, individuais, grupais ou simplesmente fictícios. ${ }^{20}$ Por isso, a cultura pós-moderna se tornou o porto seguro daqueles que defendem a satisfação aqui e agora, tornando-se avessa aos valores que conferem sentido para a vida.

Esse direito ao prazer provocou no contexto pós-moderno um dilema que reduziu a concepção de prazer no horizonte da humanidade, pois o prazer é uma experiência profunda de felicidade que se manifesta também através de sensações corporais. Tal experiência permite que a pessoa em suas ações possa fluir tranquilamente em harmonia com o ambiente em que vive. Sendo assim, é empobrecedor reduzir a concepção genuína do prazer apenas ao entretenimento, à ingestão de uma comida saborosa ou até mesmo ao puro e simples ato sexual. Desta forma, ao reduzir o prazer a certas coisas, mergulhase numa ilusão e a pessoa tenta buscar o prazer a qualquer custo. E quanto mais se busca o prazer de qualquer jeito, mas ele escapa de suas mãos. ${ }^{21}$

Segundo Almeida, uma ideia forte que subjaz na mentalidade pósmoderna no que diz respeito ao corpo e ao prazer, é a de que o ser humano é um acumulador e colecionador de sensações. ${ }^{22}$ Isso, de certa forma, proporciona nos sujeitos uma mentalidade fragmentada porque, em busca de um maior número de sensações, os indivíduos anseiam viver sem responsabilidades, sem compromissos com nada e com ninguém, e sua preocupação reside apenas em cuidar de si mesmos. ${ }^{23} \mathrm{E}$ tudo isso chega a ser

\footnotetext{
${ }^{18}$ ALMEIDA, A. L. B., A tirania do prazer e do corpo fragmentado em questão, p. 41.

${ }^{19}$ ALMEIDA, A. L. B., A tirania do prazer e do corpo fragmentado em questão, p. 47.

${ }^{20}$ LIPOVESTKY, G. apud ALMEIDA, A. L. B., A tirania do prazer e do corpo fragmentado em questão, p. 47.

${ }^{21}$ JESUS, A. M. G.; OLIVEIRA, J. L. M., Teologia do prazer, p. 29.

${ }^{22}$ ALMEIDA, A. L. B., A tirania do prazer e do corpo fragmentado em questão, p. 59.

${ }^{23}$ BAUMAN, Z., A arte da vida, p. 27.
} 
nefasto porque, de certa forma, cria indivíduos narcisistas, vazios, desenvoltos e apáticos.

Tal descrição antropológica projeta uma análoga referência ao superhomem nietzschiano, ${ }^{24}$ que aposta na vida instintiva, na intensificação dos sentidos e do prazer. Ele se entrega ao presente e ao prazer, ao consumo e ao individualismo. Neste contexto, assistimos cada vez mais a uma mercantilização do prazer sem precedentes.

O shopping se tornou o altar pós-moderno, ${ }^{25}$ pois é nele que a busca do prazer acontece de modo frenético, promovendo um culto à satisfação instantânea do prazer, sem espaço para espera, para o encontro e para a interação com o outro. De certa forma, buscar o prazer nos shoppings, por exemplo, é uma terceirização da procura do prazer, ao passo que delegamos às empresas e ao comércio a tarefa de encontrar o prazer que buscamos. ${ }^{26}$

Diante dessa condição cultural muito intensa, Bauman surge como uma voz questionadora da atual conjuntura e afirma que vivemos numa época de um erotismo "sem amarras", solto, sem rédeas, ou seja, na pós-modernidade, o erotismo é livre para entrar e sair de qualquer associação por conveniência, mas também é uma presa fácil para forças ansiosas por explorar seus poderes sedutores. ${ }^{27}$ Também podemos afirmar que inclusive a moda e a publicidade têm como missão a erotização do nosso cotidiano.

A sociedade pós-moderna fez do prazer um ideal de civilização que implica não somente o conforto material, mas também a tranquilidade emocional. Não é à toa que a busca pelo prazer hoje se torna cada vez mais refinada, cujos objetos são mais estéticos e sofisticados. Neste sentido, a mercadoria se torna um fetiche mais sedutor e o corpo ganha mais erotismo, usufruindo demasiadamente dos cosméticos, das turbinagens fisiológicas, assim como pelos resultados obtidos pela frequência às academias de ginástica. ${ }^{28}$

Entretanto, essa mercantilização da busca do prazer acaba por provocar medo. Como o final é imprescindível em todas as coisas, tem-se medo de que essa busca termine e ocasione o fim do próprio prazer. E como na pósmodernidade paira uma nuvem de permanente insatisfação, torna-se cada vez mais perceptível que uma simples compensação não gera verdadeiro prazer, justamente porque os anseios humanos são muito mais profundos do que aquilo

\footnotetext{
${ }^{24}$ NIETZSCHE, F., Assim falou Zaratustra, p. 13.

${ }^{25}$ SANTOS, J. F., O que é pós-moderno?, p. 10.

${ }^{26}$ JESUS, A. M. G.; OLIVEIRA, J. L. M., Teologia do prazer, p. 136.

${ }^{27}$ BAUMAN, Z., A sociedade individualizada, p. 279.

${ }^{28}$ BOFF, C., O Livro do Sentido, p. 383-384.
} 
que um cartão de crédito possa comprar. Em linhas gerais, em um ambiente capitalista e neoliberal, o prazer se resume ao consumo exacerbado, gerando uma felicidade efêmera, que se reduz à esperança de ser feliz. ${ }^{29}$

Acontece que uma coisa é o prazer como componente de uma vida, outra coisa é o prazer isolado, como se tivesse razão de ser em si mesmo. Nesta última condição o prazer absolutizado acaba se transformando num tirano, que escraviza as outras pessoas e acaba por escravizar o próprio sujeito do prazer. ${ }^{30}$ Toda esta situação traz consigo uma nova forma de prazer que, desconsiderando o tempo de conquista e de encantamento, acaba realizando uma "objetificação" do outro. O imediatismo para se começar uma relação tem a mesma duração e rapidez para o seu término. E o produto deste frenético modo de vida é uma busca incessante por sexo "fast-food" que na contemporaneidade é até amparado por aplicativos que sustentam esse fim.

Segundo Boff, a maior vítima da proposta hedonista é justamente a juventude. Isso porque, para um jovem pós-moderno, a vida deixa de ser um caminho percorrido de forma valente rumo a um destino para se tornar uma viagem turística, ficando apenas com o que é divertido, curioso e agradável. Por isso, sem um projeto de vida e sendo apenas regido pelo imediatismo hedonista, o jovem se entrega a uma vida de experimentar tudo que aparece em seu caminho, tirando proveito e prazer de tudo. ${ }^{31}$

Ainda neste contexto, é provável que quando se fala em prazer possa-se pensar que o cristianismo e qualquer forma de expressão religiosa seja avessa à busca do prazer. Produto disto sejam talvez as marcas e heranças que a culpa remetida ao prazer deixou no decorrer da história. Mas, se se observa o cristianismo em sua raiz mais pura, é possível perceber que "a energia produzida pelo prazer é de suma importância para a vitalidade do cristianismo, e o fato de reprimir o prazer, serve para criar cristãos que veem ignorância e perversidade por toda a parte". 32

Deste modo, é preciso, no cenário pós-moderno, resgatar a máxima categórica de que o cristianismo é uma religião da alegria, do prazer, do gozo e da felicidade. Neste ínterim, ao afirmar que o prazer é uma realidade intrinsecamente humana, um cristianismo que pretendesse afastar os sujeitos de sua condição humana, estaria traindo a sua própria essência porque, para realizar o plano de seu Pai, o próprio Jesus decidiu humanizar-se. Em suma, é

\footnotetext{
${ }^{29}$ JESUS, A. M. G.; OLIVEIRA, J. L. M., Teologia do prazer, p. 136-137.

${ }^{30}$ MOSER, A., Corpo e sexualidade, p. 52.

${ }^{31}$ BOFF, C., O Livro do Sentido, p. 385.

32 JESUS, A. M. G.; OLIVEIRA, J. L. M., Teologia do prazer, p. 185.
} 
preciso romper com um tipo de cristianismo que apresenta o prazer e a vida prazerosa como contrários ao projeto de Deus. ${ }^{33}$

Em virtude do que foi mencionado, tendo como intenção combater os prazeres que nos desumanizam, é preciso fomentar novas formas de cultura que visem a uma valorização plena do prazer. Por isso, com o intuito de superar os dilemas do prazer na cultura pós-moderna e, assim, favorecer uma íntegra formação das consciências, a vivência do corpo e do prazer na sociedade atual precisa ser considerada por meio de um viés ético, cujo despertar seja baseado na prudência e no discernimento, propondo e não impondo formas educativas para enxergar o prazer a partir de uma visão integral.

Sendo assim, quando não se compreendeu no decorrer da história que o prazer é uma realidade profundamente humana, ele foi consideravelmente associado à culpa, deixando fortes marcas na tradição cristã, como foi possível observar. E especificamente agora, na pós-modernidade, o prazer se deslocou de uma visão antropológica integral para uma perspectiva fragmentada e reducionista. Portanto, diante deste dilema, é necessária uma reflexão acerca da formação da consciência, que, sob uma ótica ético-teológica, seja possível encontrar meios propositivos e educativos em vista de valorizar o prazer no seu sentido mais pleno.

\section{3. Ética cristã e consciência: o desafio formativo do prazer na pós- modernidade}

Tratar da relação entre ética, consciência e pós-modernidade impõe-se como uma tarefa árdua, ainda mais no contexto formativo. Refletir sobre a Teologia na pós-modernidade é tarefa sujeita a muitas ambiguidades, resultantes da ambivalência do conceito em causa. O tema do prazer é caracterizado como um constante desafio dentro do quadro religioso convencional, já que se refere às forças humanas mais profundas a serem constantemente integradas no todo da personalidade.

O modo de viver cristão é devedor de uma longa tradição de leitura e interpretação do que foi transmitido oralmente e posteriormente redigido em contextos próprios. A tida "moral cristã", deste modo, carrega uma longa tradição que se fundamenta na leitura e releitura de textos bíblicos, sobretudo do Novo Testamento, capazes de indicar os valores essenciais

33 JESUS, A. M. G.; OLIVEIRA, J. L. M., Teologia do prazer, p. 191-193. 
e necessários para se vivenciar o que foi transmitido como fundamento do modo de ser de Jesus Cristo. ${ }^{34}$

"Estamos vivendo a passagem de uma cultura essencialmente 'logocêntrica' a uma perspectiva mais 'somatocêntrica', ${ }^{35}$ que tende a restituir ao corpo o seu lugar e a sua importância como locus fidei e locus theologicus". ${ }^{36}$ Este é um complexo desafio para quem pensa e produz reflexão em ética cristã. A consciência contemporânea está fortemente marcada por uma centralidade no sujeito e a sua busca por impor-se como referência última das suas decisões e a própria liberdade.

O sujeito que vive os seus dramas morais busca, no próprio corpo e nos outros corpos, uma forma de realização, sentido e encontro que é construída por ele mesmo à medida que ressignifica sua vida com os valores interiorizados. Nada mais justo, portanto, que conceber o sujeito contemporâneo como 'homo somaticus' ou 'homo aestheticus'. ${ }^{37}$

O desafio da formação da consciência das pessoas hoje é uma questão que não só atinge a fé cristã no seu sentido de discipulado de Jesus Cristo, mas de sobrevivência do próprio humano no tecido social. Eis porque é urgente e fundamental propor uma moral da "prevenção" diante do "apressamento" da vida, da dificuldade em refletir com profundidade e de reduzir a moralidade das questões à sua dimensão deontológica.

A pós-modernidade, caracterizada como uma era de continuação com a da modernidade, lentamente vai se afirmando como um momento da história em que o vazio e o sentido do "light" impõem-se no contexto dos valores éticos das pessoas. ${ }^{38} \mathrm{O}$ ser humano que corresponde a essa era ou é um homem desesperado perante a falta de orientação ou é um homem que se habituou a viver no vazio, que se aceitou habitante desse radical niilismo. É certo que esta condição pós-moderna de viver impactará os valores tradicionais disseminados pela religião e a experiência consequente.

Uma das críticas que se pode fazer ao lugar do prazer, do corpo e da sexualidade no contexto pós-moderno, é que estas essenciais esferas ou

\footnotetext{
${ }^{34}$ ALMEIDA, A. L. B.; FERREIRA, L. E.; MELO, A., A formação da consciência em uma cultura de "sujeitos bolhas" cristãos, p. 159-160.

${ }^{35}$ Expressão presente em GALANTINO, N., Dizer homem hoje, p. 147-148.

36 ALMEIDA, A. L. B., Prevenir contra o dualismo e a fragmentação, p. 99.

${ }^{37}$ ALMEIDA, A. L. B., Prevenir contra o dualismo e a fragmentação, p. 99-100.

${ }^{38}$ DUQUE, J. M., Para o diálogo com a pós-modernidade, p. 126.
} 
dimensões da pessoa foram isoladas dos vários aspectos do relacionamento social. Em geral, o eros se tornou uma força independente que ganhou cidadania. Desta orientação surge uma consciência em perplexidade com dificuldade de interação ampla entre as dimensões da pessoalidade. Os indivíduos, neste horizonte, são socialmente empenhados mais como consumidores que como produtores conscientes de si mesmos, já que o estímulo de novos desejos toma o lugar da regulação normativa, a publicidade toma o lugar da coerção, e a sedução torna redundantes ou invisíveis as pressões da necessidade. ${ }^{39}$

A derrocada dos valores que sustentavam a cultura ocidental e a própria modernidade é acompanhada, como seria de esperar, de uma profunda crise ou mesmo derrocada das instituições religiosas que lhes estavam ligadas, mormente das Igrejas cristãs. Esse processo instiga a uma retomada de um sentido alegre e positivo diante da vida e do prazer. ${ }^{40} \mathrm{Se}$, de um lado, os valores rígidos e autoritários entram em crise nesse complexo processo, brota, de outro lado, uma consciência crítica de retomada de valores humanos, corporais e do próprio prazer em relação ao evangelho.

Neste contexto de crise emerge a importância da formação da consciência do cristão e do sentido do prazer em meio à dita cultura do pensamento frágil. É desse ethos frágil que se pode aproveitar o aspecto educativo como possibilidade de liberdade e responsabilidade frente ao macrossistema. ${ }^{41}$ Há, neste sentido, um aspecto pedagógico da tradição cristã a ser recuperado em constante proposta de humanização e integração do ser humano total. Mas para que este caminho seja possível é necessário tomar consciência das camadas de opressão que o prazer vivido fora do conjunto humano pode ocasionar na profundidade do humano, impedindo que o sujeito seja o protagonista da sua própria vida.

Com o avanço da tecnologia, da complexidade dos padrões culturais, do pluralismo dos estilos de vida e dos valores, os dilemas sobre o que pensar e o que o fazer são geradores de uma constante tomada de decisões. A resposta a estas decisões depende sobremaneira do vínculo que a pessoa estabelece com o contexto social e com sua consciência. ${ }^{42}$ Deste modo, do ponto de vista ético, a

\footnotetext{
${ }^{39}$ BAUMAN, Z., O mal-estar da pós-modernidade, p. 185.

40 JESUS, A. M. G.; OLIVEIRA, J. L. M., Teologia do prazer, p. 175.

${ }^{41}$ ALMEIDA, A. L. B., Moral Social, p. 43.

42 ALMEIDA, A. L. B.; SILVA, L. E. F.; MARTINS, M. R. M., Novos ventos de fundamentalismo religioso no Brasil, p. 20.
} 
formação da consciência é essencial para a uma pedagogia do prazer no contexto pós-moderno, visando à unidade interior do sujeito.

$\mathrm{Se}$, de um lado, o atual contexto pós-moderno questiona todo tipo de pessimismo antropológico do passado que impede a uma unidade do prazer e do corpo na sexualidade, por outro, nem sempre oferece luzes para que o sujeito possa ter forças no caminho de sua própria integração. A sexualidade hoje assumiu o prazer como uma dimensão estrutural e essencial da própria constituição da existência pessoal. ${ }^{43}$ Essa perspectiva é o próprio reconhecimento de que o prazer é uma dimensão da unidade de cada ser humano chamado a se realizar quando toma consciência das suas forças presentes em sua corporeidade. Assim, o prazer está totalmente envolvido nessa consciência da unidade a ser sempre integrada.

Outro elemento de relação entre o prazer e a consciência está na dimensão da linguagem. Do ponto de vista ético, alicerçado em uma antropologia cristã, a sexualidade é expressão de uma relação a ser estabelecida na capacidade que uma subjetividade possui em entrar numa profunda busca por um outro. ${ }^{44}$ Há que se aprofundar este elemento no atual contexto pósmoderno, centrado mais sobre sujeitos narcísicos e ensimesmados. Entretanto, a força do prazer no contexto mais amplo do amor localiza-se como energia que conduz a pessoa à sua força mais profunda de realização humana. ${ }^{45}$

Do ponto de vista formativo impõe-se o desafio de repropor a integração do prazer ao corpo e à sexualidade em uma visão positiva. Deve-se compreender a realização do prazer além da esfera física genital e compreendêla em sua rica possibilidade de relação interpessoal. Esta perspectiva é assumida pelo Papa Francisco na Amoris Laetitia quando diz que,

Assim, não podemos, de maneira alguma, entender a dimensão erótica do amor como um mal permitido ou como um peso tolerável para o bem da família, mas como dom de Deus que embeleza o encontro dos esposos. Tratando-se de uma paixão sublimada pelo amor que admira a dignidade do outro, torna-se uma afirmação amorosa plena e cristalina, mostrandonos de que maravilhas é capaz o coração humano, e assim, por um momento, sente-se que a existência humana foi um sucesso. ${ }^{46}$

\footnotetext{
${ }^{43}$ PIANA, G., La sessualità umana, p. 17.

${ }^{44}$ GAYON, J., Por que o sexo?, p. 79.

${ }^{45}$ LEONE, S., Il rinnovamento dell'etica sessuale, p. 104.

${ }^{46}$ AL 152.
} 
Esta visão do magistério atual da Igreja, alicerçada numa antropologia integrativa e positiva do prazer, apresenta-se com uma possibilidade dialógica de superação de um certo dualismo que imprimiu uma visão negativa do corpo e sexualidade. Assim, ao falar em corporeidade e consciência na cultura pósmoderna, é imprescindível retomar a visão de que cada pessoa é responsável pela sua própria ação diante de limites a serem superados. Enfim, nas devidas proporções, cabe a máxima de Galeano: "A Igreja diz: o corpo é uma culpa. A ciência diz: o corpo é uma máquina. A publicidade diz: o corpo é um negócio. O corpo diz: Eu sou uma festa". ${ }^{47}$

\section{Conclusão}

O ser humano diferencia-se do animal porque seu destino não está traçado no automatismo do instinto, não é coisa acabada, justaposição de órgãos e vida animada, mas sujeito que se autoconstrói permanentemente na história. É sujeito não definido. É sujeito chamado a dilatar suas múltiplas potencialidades e limites. O aspecto educativo da ética torna-se urgente no atual contexto pós-moderno reinante e abrangente. Encontramo-nos, deste modo, no que tange à questão do prazer, do corpo e da sexualidade diante de uma possibilidade e desafio: repropor ao sujeito cristão pós-moderno a sua intransferível possibilidade de integração mediante a própria consciência.

A Teologia na pós-modernidade é chamada a encontrar o seu lugar de reflexão propositiva. Do ponto de vista ético, a sabedoria cristã milenar exprimiu a realização do prazer no contexto do amor em sua unidade física e espiritual. A retomada dessa unicidade antropológica é um projeto de esperança diante de reducionismos e novos rigorismos emergentes intra e extra eclesiais. O contexto pós-moderno faz emergir toda a dimensão dos apetites e afetos existentes na pulsão sexual. A tradição cristã conduz a uma orientação dessa força para uma experiência integradora do amor.

Tanto o corpo como o prazer, dimensões inerentes e inseparáveis do ser pessoal, exprimem a diversidade presente na unidade indivisível. Cada ser humano possui um corpo e um prazer únicos, irrepetíveis e instransferíveis. A Teologia tradicional, com sua orientação universalista e racionalista, não era capaz de perceber essa realidade que as correntes contemporâneas afirmam, principalmente o existencialismo, a fenomenologia e a psicanálise. Esta perspectiva mais dinâmica e profunda torna eloquente a capacidade humana de construir e refazer elementos do corpo que tocam à sua sacralidade. No contexto

${ }^{47}$ GALEANO, E., As palavras andantes, p. 138. 
pós-moderno, impõe-se à Teologia Cristã, da encarnação à ressurreição; da Eucaristia à Eclesiologia, corpo de Cristo no mundo; enfim, na própria vida nova e eterna ressurreição dos corpos dos cristãos no corpo de Cristo.

\section{Referências bibliográficas}

ALMEIDA, A. L. B. A tirania do prazer e do corpo fragmentado em questão: uma proposta ético-educativa num contexto pós-moderno. São Gonçalo dos Campos: Editora Tenda do Livro, 2019.

ALMEIDA, A. L. B. Moral Social. Iniciação à Teologia. Petrópolis: Vozes, 2021.

ALMEIDA, A. L. B. Prevenir contra o dualismo e a fragmentação. O dualismo e a fragmentação do corpo: uma reflexão ético-propositiva de inspiração cristã. In: TRASFERETTI, J. A.; COELHO, M. M. ZACHARIAS, R. Teologia da Prevenção: por um caminho de humanização. São Paulo: Paulus, 2021. p. 87-113.

ALMEIDA, A. L. B.; FERREIRA, L. E.; MELO, A. A formação da consciência em uma cultura de "sujeitos bolhas" cristãos. Uma análise ético-teológica propositiva a partir da moral social do Papa Francisco. Encontros Teológicos, v. 36, n. 1, p. 153-172, jan./abr. 2021.

ALMEIDA, A. L. B.; SILVA, L. E. F.; MARTINS, M. R. M. Novos ventos de fundamentalismo religioso no Brasil. Colonização midiático-digital na formação da consciência. Revista Eclesiástica Brasileira, v. 81, n. 318, p. 829, jan./abr. 2021.

BAUMAN, Z. A arte da vida. Rio de Janeiro: Zahar, 2009.

BAUMAN, Z. O mal-estar da pós-modernidade. Rio de Janeiro: Jorge Zahar Editor, 1998.

BÍBLIA DE JERUSALÉM. São Paulo: Paulus, 2011.

BOFF, C. O Livro do Sentido. Crise e busca de sentido hoje (parte críticoanalítica). São Paulo: Paulus, 2014. v. I.

CASTILHO, J. M. A ética de Cristo. São Paulo: Edições Loyola, 2010.

CIRINO, O. O desejo, os corpos e os prazeres em Michel Foucault. Mental, v. 5, n. 8, p. 77-89, jun. 2007. Disponível em $<$ http://pepsic.bvsalud.org/scielo.php?script=sci_arttext\&pid=S167944272007000100006\&lng=pt\&nrm=iso>. Acesso em: 11 jul. 2021. 
DUQUE, J. M. Para o diálogo com a pós-modernidade. São Paulo: Paulus, 2016. (Coleção teologia em saída).

FOUCAULT, M. História da sexualidade I: a vontade de saber. São Paulo: Paz e Terra, 2019.

FOUCAULT, M. História da sexualidade IV: as confissões da carne. Lisboa: Relógio D’Água Editores, 2019.

FRANCISCO, PP. Exortação Apostólica Amoris Laetitia sobre o amor na família. São Paulo: Paulus, 2016.

FRANCISCO, PP. Exortação Apostólica Gaudete et Exsultate sobre o chamado à santidade no mundo atual. São Paulo: Paulus, 2018.

FRENI, C. Homo Aestheticus. La bellezza come cura per l'antropologia del nostro tempo. Studia Moralia, v. 54, n. 2, p. 251-272, 2016.

GALANTINO, N. Dizer homem hoje. Novos caminhos da antropologia filosófica. São Paulo: Paulus, 2003.

GALEANO, E. As palavras andantes. Porto Alegre: LPM, 1994.

GAYON, J. Por que o sexo? Um século de debates evolucionistas. In: FÉDIDA, P. (Org.). A sexualidade tem futuro? São Paulo: Loyola, 2002. p. 73-94.

GIDDENS, A. A transformação da intimidade: sexualidade, amor e erotismo nas sociedades modernas. São Paulo: Editora da Universidade Estadual Paulista, 1993.

JESUS, A. M. G.; OLIVEIRA, J. L. M. Teologia do prazer. São Paulo: Paulus, 2014.

JOÃO PAULO II, PP. Carta Encíclica Veritatis Splendor sobre algumas questões fundamentais do ensinamento moral da igreja. São Paulo: Paulinas, 1993.

JOÃO PAULO II, PP. Homem e mulher o criou: catequeses sobre o amor humano. Bauru, SP: EDUSC, 2005.

LEONE, S. Il rinnovamento dell'etica sessuale. Bologna: Edizioni Dehoniane, 2017.

MONDIN, B. O homem, quem é ele? Elementos de Antropologia Filosófica. São Paulo: Paulus, 2008. 
MOSER, A. Corpo e sexualidade: do biológico ao virtual. Revista Eclesiástica Brasileira, v. 73, n. 289, p. 38-68, out. 2013.

NIETZSCHE, F. Assim falou Zaratustra: um livro para todos e para ninguém. São Paulo: Companhia das Letras, 2011.

PIANA, G. La sessualità umana. Una proposta etica. Vila Verucchio: Pazzini Stampatore Editore SRL, 2007.

RANKE-HEINEMANN, U. Eunucos pelo Reino de Deus: Igreja Católica e sexualidade - de Jesus a Bento XVI. Rio de Janeiro: Rosa dos Tempos, 2019.

SALZMAN, T. A.; LAWLER, M. G. A pessoa sexual: por uma antropologia católica renovada. São Leopoldo: Unisinos, 2012.

SANTOS, J. F. O que é pós-moderno? São Paulo: Brasiliense, 1986.

ZACHARIAS, R. Repensar a moral sexual: uma leitura da sexualidade à luz dos fundamentos da moralidade propostos por Francisco. In: ZACHARIAS, R.; MILLEN, M. I. C. (Org.). A moral do Papa Francisco: um projeto a partir dos descartados. São Paulo: Editora Santuário, 2020. p. 283-330.

André Luiz Boccato de Almeida Doutorado em Teologia Moral pela Pontifícia Universidade Lateranense

Docente na Pontifícia Universidade Católica de São Paulo São Paulo / SP - Brasil E-mail: a.1.boccato@gmail.com

\section{Lúcia Eliza Ferreira da Silva}

Mestranda em Teologia na Pontifícia Universidade Católica de São Paulo São Paulo / SP - Brasil E-mail: lucia.elizaazile@gmail.com

Recebido em: 26/07/2021

Aprovado em: 10/12/2021 